\title{
BOEREKRYGSGEVANGENES IN CEYLON
}

\author{
"A PRISONER OF WAR HAS NO RIGHTS" \\ "We can do what we like with a prisoner of \\ war; we only have to keep him alive..." \\ (Engelse offisier aan \\ Boere krygsgevangene)
}

Oorlog bly oorlog en die krygsgevangene word nie uitgesonder nie. Wanneer hy sy vryheid verloor, bevind hy hom onder ellendige, skandelike omstandighede. Afgesonder van die wêreld, moet hy in sy vernedering probeer om die vervelige dae deur te bring totdat die uur van vryheid aangekondig word.

Alhoewel die Tweede-Vryheidsoorlog (18991902) nou aan die verlede behoort, is dit te betreur dat navorsing oor die Afrikaner-krygsgevangenes nog uiters beperk is. Miskien is dit vergete omdat dit buite die terrein van die militêre en politieke geskiedkundiges lê. Volgens skrywer hiervan se mening, behoort navorsing op die gebied van krygsgevangenes, eerder aan die kultuur-historikus as aan die militêre historikus, aangesien die kultuurhistorikus buite die oorlog staan. Dit is interessant om vas te stel hoe die Afrikaner hom by veranderde omstandighede aangepas het, hoe sy nasionale kenmerke as banneling na vore gekom het, hoe hy probeer het om sy identiteit te behou, en op 'n klein skaal, 'n "volksplanting" onder vreemde en tragiese omstandighede te skep en ontwikkel. Die verhaal van die Afrikaner-krygsgevangenes op Ceylon bied 'n interessante beeld - omstandighede was soms onaangenaam, maar in sommige opsigte, was dit ook aangenaam. 'n Insiggewende en waardevolle beskrywing vind ons in die boek "Ceylon en de Bannelingen" deur J. N. Brink (1904) waarin die skrywer gedetailleerde aantekeninge van sy ervarings in die Krygsgevangenekampe aanbied. Nou, na die verloop van 70 jaar kan ons hierdie treurige bladsy uit ons geskiedenis meer objektief beskou. Verder, kan ons as gevolg van dokumente wat nou aan die lig gekom het, tot die gevolgtrekking kom dat omstandighede in die krygsgevangene-kampe glad nie so ongunstig was nie. Brink skryf op 16 Mei 1901, dat in plaas daarvan dat alles somber is,

"leder scheen tevreden en zelfs blijmoedig. Men hoorde veel meer lachen dan zuchten. Waarlik! ons volk draagt zijn hart niet op zijn mouw" (bl 163).

Hier in twee sinne vind ons die opsomming van 'n baie interessante kenmerk van die Afrikaner - hoe hy alles in sy vermoë gedoen het om die eentonige, vervelige ure in die kamp deur te bring, en dat ten spyte van sy ellendige omstandighede, hy probeer het om sy lewe te verryk en sy moraal hoog te hou.

Vanaf Junie 1900 het die eerste krygsgevangenes in Ceylon aangekom en teen die einde van die jaar was daar altesame 4735 krygsgevangenes, waarvan ongeveer 4000 hulle in die Diyatalawakamp bevind het. Europese vrywilligers vanaf Holland, Duitsland, Frankryk en ander lande, was na die Ragamakamp gestuur. Mt Lavinia was die hospitaalkamp en daar was ook twee kleiner kampe (Hambantota en Urugasmanuandiya), waarvan ons minder weet. Hierdie besluit om alle krygsgevangenes na oorsese lande van die Britse Statebond te stuur, was natuurlik 'n groot morele oorwinning vir die oorwinnaar. Ons dink dadelik aan die woorde uit ons bekende "Sarie Marais":

"Ek was so bang dat die Kakies my sou vang,

En ver oor die see wegstuur." 
Behalwe vir die Europese krygsgevangenes, het die groot meerderheid van die Afrikaners nooit hulle geboorteland verlaat nie. Die atmosfeer van Ceylon was vir hulle vreemd . . . dit was 'n warm tropiese klimaat, vol koelies en muskiete, met ongeveer 200 duim reën per jaar — 'n onontwikkelde land waar hongersnood algemeen was onder die laer klasse. Brink sê alles is "mager" . . . "alles mager, eene uitzondering, de spoorweg, hoeveel niet vet, is zeer breed". Aangesien Ceylon vir ongeveer 150 jaar 'n Hollandse kolonie tot 1795 was, was daar ongeveer 800 lede van die NG Kerk te Colombo. Hierdie groep, wat hoofsaaklik uit staatsamptenare bestaan het, was in onguns by die owerheid. Sonder sterk leiding, het geestelike agteruitgang ingetree en teen 1902 was hulle kerkdiens in Engels. Hulle was heel simpatiek teenoor die krygsgevangenes en het hulle met die lot van die Boere vereenselwig. Die merkwaardigste verskil was dat die Boere huistoe wou keer. 'n Onbekende banneling som sy gevoelens in hierdie vers op:

Hier zit de balling. O! wat ramp!

Balling in Diyatalawakamp.

Sla mijn ellenda ga!

Ceylon! uw schoonheid streelt mij niet, Brengt mij geen troost in mijn verdriet. ‘k Verlang na Afrika.

\section{Die Diyatalawakamp:}

Die woord kom van die Singhalese "diya" (water bronne) en "talawa" (golwende vlakte) en beteken dus "die vallei van die waterbeke". In vroeër jare het die plek "The Happy Valley" (Die Gelukkige Vallei) geheet, en is so benoem deur die eerste Wesleyaanse Sendeling toe hy hierdie terrein vir sy nuwe sendingstasie gekies het.

Teen Augustus 1900 was haastige voorbereidings nodig om al die krygsgevangenes te huisves. Hierdie kamp was ongeveer $150 \mathrm{myl}$ vanaf Colombo, en 4300 voet bo seespieël. Spesiale hutte 120 by 20 voet is opgerig en ongeveer 50 manne is onder een dak gehuisves. Hierdie kamp het uit twee dele bestaan, "Krugersdorp" en "Steijnsburg" (genoem na die twee presidente), en op 'n kopjie tussen die twee dorpies, was die sinkhuisies van Generaals Roux en Olivier. Hut No 27 (en later ook No 36) was alleenlik vir die gebruik van Boere-offisiere. Hierdie hut is op meer gerieflike wyse gemeubileer en het selfs 'n plafon en toilet fasiliteite gehad: Offisiere het op beddens met matrasse geslaap en het elk 2 komberse, 2 lakens, 'n handdoek en kussingsloop ontvang. Omstandighede vir die gewone man was natuurlik minder gunstig. Offisiere en predikante kon buite die kamp gaan wandel asook spesiale passe ontvang om Colombo en ander dorpies te besoek. Die feit dat spesiale voorsiening gemaak is vir die gerief van die Boere-offisiere, is alreeds merkwaardig. Administrasie in die kamp self was verdeel onder die manne, soos bv, die korporaal van 'n tafel, die kaptein van 'n hut, die sersant van sy straat, ens.

Hoe het die bannelinge die tyd deurgebring? Daar was die daaglikse pligte soos koskook, klerewas, hutte skoonhou en vuurhout buite die kamp bymekaarmaak. Brink beweer "velen, wellicht de meesten, doen niets dan slapen, eten, rondslenteren en gezelsen" (bl 127). Tog was die manne heel bedrywig. As gevolg van katkisasie en Bybelklasse, het hierdie bedrywigheid gou in 'n skool van 300 leerlinge onder leiding van 6 onderwysers, uitgebrei. Elementêre onderwys, moderne tale (Hollands, Frans, Duits) en selfs meetkunde was aangebied. Aan die begin was daar 'n gebrek aan leermiddels en boeke, maar in dié opsig, was die insittendes baie vindingryk. Elke hut het byvoorbeeld 'n Bybel besit wat daagliks aan die skool geleen is en wat as leerboek gebruik is. Met behulp van fondse uit Holland en Suid-Afrika, is meer boeke gekoop en selfs die onderwysers het R4 per maand (30 Rupee) ontvang.

Hutte Nos 27 en 36 was ook gebruik as leeskamers, wat goed voorsien was van geestelike en ander werke. Die dagblaaie van Colombo en selfs oorsese koerante was beskikbaar. Blaaie wat "onvriendelik" was teenoor Engeland was verbied, maar nogtans was hulle ingesmokkel.

Van merkwaardige betekenis was die stigting van 'n kampkoerant, "Diyatalawa Dum-Dum", wat op 10 September 1900, sy verskyning gemaak het. Miskien wou die owerhede die manne besig hou, maar dit spreek vanself, dat ' $n$ koerantjie in die hande van opstandige krygsgevangenes, 'n baie gevaarlike risiko kon geword het. Hierdie klein blad, wat oorspronklik uit net een bladsy bestaan het, het ongetwyfeld die literêre talente van die manne 
gestimuleer. Nogtans moes die redakteur versigtig trap. Hy skryf in Engels, en rig 'n baie duidelike boodskap van dankbaarheid aan die twee Engelse bevelvoerders, kol Vincent en kol Tesse-Coope, veral wanneer hy skryf:

"if fate was unkind in sending us against our will to see the beauties of Ceylon, she has been kind in placing us under humane officers ..."

Brink maak geen melding van hierdie blad nie, maar beskryf Coope as "een welmeenende, maar lastige bemoeial", en Vincent as "een boefachtige Schotsche krijsoverste".

Sport was ook baie populêr en die Nuwejaarsport was 'n groot geleentheid. Van betekenis was die feit dat wedrenne volgens ouderdomme ingedeel is, en dat "juniors", d w s seuns 20 jaar en onder, in hulle eie kompetisies kon deelneem. "Vrystaat" teen "Transvaal" was gewoonlik die twee spanne in kompetisies soos toutrek.

Brink maak ook geen melding van Boks nie, nogtans het die skrywer 'n paar programme hieroor raakgeloop. Hierdie gesellighede het gewoonlik na die $7.30 \mathrm{~nm}$ "Roll-Call" plaasgevind. Op 10 November 1901, vind ons die volgende gevegte op die program: tussen kommandant Van Zyl en Heittman van Duitsland, wat in "Graeco-Roman" style oor 4 rondtes kon veg. 'n Tweede geveg was tussen Artie Tully en luit Francois van die Franse Leër. "The combatants could fight in their own national style", Tully slegs met die vuis, terwyl Francois kon "kick and hit". Hierdie was blykbaar 'n kombinasie van boks-enstoeimetodes. Die derde en laaste geveg, was oor 10 rondtes tussen Lewerenz van Duitsland en "Long-Tom" Fisher van Johannesburg. Artie Tully, wat homself beskryf het as die "ligsgewig" kampioen van Australië, asook van Suid-Afrika, was 'n ywerige promotor van hierdie sportsoort. Jim Holloway, as “kampioen" van Suid-Afrika, het ook 'n leidende rol in die organisasie van hierdie gevegte gespeel. Hierdie gesellighede het op 'n klein skaal onskuldige dobbelary onder die mans gestimuleer, 'n onheil waarteen die godsdienstige Brink beswaar gemaak het.

Commissarisstraat, die straat tussen die twee dorpies, het bestaan uit 'n aantal winkeltjies, waarin die gelukkiges wat geld besit het, "bijna alles kan koopen". Die 6 by 6 voet winkeltjies was "samengelapt" en alle winkeliers moes 'n lisensie van 1 rupee per maand betaal. Buite die kamp was daar ook 'n koeliewinkel. Die bedrywighede het moontlik ontstaan as gevolg van die slegte kos in die kamp.

Volgens die uitgawe van die kampblad, was daar 'n verskeidenheid van aktiwiteite. Die vervaardiging van "curios" soos wandelstokke, pype, portretrame, servetringe en selfs ' $n$ treinmodel en 'n draaiorrel, uit die eenvoudigste van gereedskap, getuig van die vakmanskap en geduld van die bannelinge. Die bewoners van sommige hutte was vol ondernemingsgees. ' $n$ Voorbeeld daarvan is dat dié in Hut No 14 hulself adverteer as "The Happy Valley Beer Hall", en blykbaar dan ook bier (of miskien koeldrank) vervaardig. Verdere aantrekkingskrag in die hut was "Professor Fraser met sy Palmistry". Afnemers wat poskaart-portrette van die insittendes van die kamp geneem het, was ook volop. Die kamp was dus in werklikheid 'n klein dorpie met verskillende "bazaars" waar goedere vertoon is. In museums oral in Suid-Afrika, vind ons nog "curios" wat die bannelinge gemaak het om die lang vervelige ure te verwyl. Die "curio" vervaardiging was nogal 'n florerende industrie, aangesien belangstellendes reg deur die wêreld bestellings geplaas het. Die geillustreerde Advertensielys lewer 'n uitstekende voorbeeld van die ondernemingsgees van die krygsgevangenes.

Die merkwaardigste rede vir die hoë moraal van die Afrikaner in sy ballingskap was die krag van sy geloof. Verskillende vereenigings soos die Christelike Strevers Vereeniging (wat ook sy eie "Drukkerij" besit het), was besonder aktief, en teen Februarie 1902, was daar 'n ledetal van 800. Aangesien daar geen kerklike verskille bestaan het nie, kon die werk van geestelike opbouing van Gods koninkryk ongehinderd voortbloei. In die begin was daar 'n gebrek aan geestelike boeke, en gevolglik moes die krygsgevangenes soms die katkisasieboeke en Psalm- en Gesangboeke uitskryf. Op hierdie wyse kon hulle ook die lang vervelige ure deurbring. Teen 1902 was daar daaglikse bidure, en by hierdie geleenthede was leẽ plekke onbekend. 


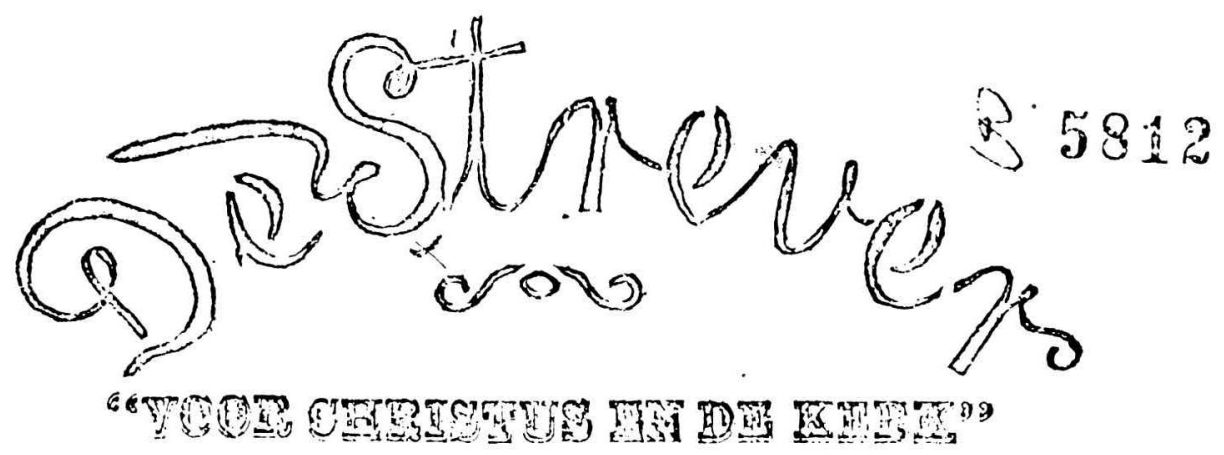

ORGAAN DER C. S. V. ONDER DE KRIJGSGLVANGENEN.

\begin{tabular}{|c|c|}
\hline Nol & Jiyatalawa-Kamp, Cey \\
\hline $\begin{array}{l}\text { INL } \\
\text { Broeders, me } \\
\text { dit blandje } \\
\text { blid zijn } \\
\text { evers Unie. } \\
\text { eenigingen i } \\
\text { der mett het } \\
\text { wel als mee } \\
\text { en te brenge }\end{array}$ & 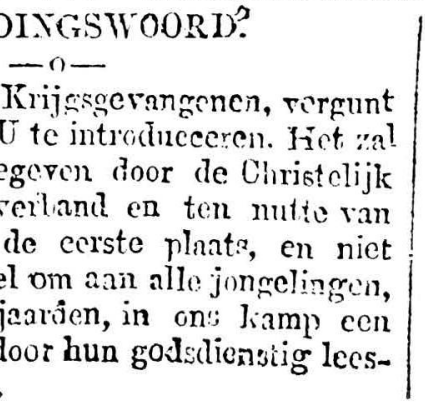 \\
\hline
\end{tabular}
s tof te verachatien.
Hierdie bloeiende geestelike lewe was hoofsaaklik te danke aan die sterk invloed van besoekende predikante soos ds Postma van Pretoria. Sy opeluggodsdiensoefeninge wat deur ongeveer 4000 manne bygewoon is, is beskryf as "zeer indrukwekkend". Die NG Kerk van die Kaap Kolonie het byvoorbeeld ds George Murray vir ' $n$ tydperk van 5 maande (10 November 1900 tot 21 Maart 1901) na Ceylon gestuur. In byna elke uitgawe van die Kerkbode gedurende die oorlogtyd, vind ons briewe van krygsgevangenes waarin hulle uiting gee aan hulle sterk en oortuigende Christelike gevoelens. H. S. Kok, 'n krygsgevangene, uit ' $n$ brief gedateer 26 Februarie 1902, skryf:

"Wij zijn door de onuitsprekelijke liefde van den lieven Heer, in Leven en in gezondheid."

Die invloed van die godsdiens is duidelik te bespeur in ' $n$ gevoel van vreugde, geduld en vertroue in die manne:

“Wij zien met verlangen uit naar den dag der verlossing. Maar wij zullen op den Heer wagten, op Zijn tijd en wijze zal
Hij ons verlossen. Wij zullen wachten op den Heer totdat Hij Zijn doel met ons bereikt zal hebben." (Kok).

Hoe paradoksaal dat bannelingskap die beste kenmerke van die Boere na vore gebring het. Met gereelde skole en godsdiensoefeninge kon Brink skryf:

"Zijn getuigen dat deze vereenigingen hier nog meer doeltreffend zijn dan in het vaderland, omdat zij beter en geregelder kunnen bijgewoond worden." (bl. 155).

Die "Strevers Drukkerij" het gereeld geestelike publikasies uitgegee (soos bv Koor Liederen) en op byna elke bladsy vind ons Christelike spreuke soos byvoorbeeld:

1. Jezus is goed voor mijn ziel.

2. Jezus is lief voor mijn ziel.

3. Jezus bewaart ook mijn ziel.

4. Jezus verlost ook mijn ziel.

5. Jezus is blijde met mij.

6. Jezus is alles voor mij.

In Desember 1901 het die CSV se weekblad "De Strever" die lig gesien. 


\section{O U DTSHOOR}

14 Maart 1902

Aande Leden der S. S. V.

Digatalawa Kamp, Ceçlon:

Zeer geliefdo brocile's on mede-leden der C.S. V.

That was het mij cene rerrassing en blijclschap toen mij .,Do strever" wcrd ter hand gesteld. Ilikon het nanwelils gelooven diat liet hial uit het liamp kwam en toch is het zoo. Iaat mij u hartolik danken voor de mij toegezcnden Nos en zeggen welk een vrougdo het mij is om u mijne inteekenings - penningen to $\theta$ to zendin en op nwe lijst ran inteekenaara to worden geplaatst,

Ook moct il u van harto geluk wensch: en lat uw blad zoo degelik is en zoo goed gedrukt worit. Iemand die het las zeide: ,Waarlik wij krijgen Zuid Afrikaasscho hienws er in. maar wij niet ran wisten!"

Fin welke herinnaringen komen mij to binnen bij het zien tan zoovelo welbekeucle namer. Het is mij of il tweer in uwe vergaderingen ben, weer een van die onvergetelilie uren mat u doorbrẹeng.

Jo Heer zerche uw blad on do rereo. niringr. Hij gebruile u tot orerrloedigen zegen vour allen in 't kamp, en ook voor velen in ons land. Het zal mij eone eer zijn om een enlele mail iets in uw blad te mo gen fliatsen. Tot wederziens.

Uw brocker in den Gelietdo. Geo, DIurray 


\section{ONS STREVERS LIED.}

Strijders zijn wij, iedereen, Met den vijand om ons heen,

Maar ons trouwe Leidsman is de Heer,

$\mathrm{Hij}$ voorziet in elken nood,

Maakt ons trouw tot in den dood,

Slaat des Satans macht ter neer.

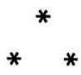

Koor. - Stapt voorwaarts dan, onzen Leidsman na.

Met heldenmoed, want dan volgt weldra De 'verwinnaars kroon.

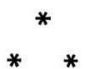

Wordt de vijand ons te sterk,

In het angstig worstelperk,

En elk hart klopt zeer benauwd en snel,

Dan staan wij tezaam geschaard,

Met des Geestes blinkend zwaard,

Als 'verwinnaars van de hel,

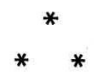

Als de zond' ons nederdrukt,

Als ons hart bezwaard, gebukt

En beangst van smart en vreeze bloedt

Dan vertrouwen wij nog meer,

Onzen sterken, dierbren Heer,

Waar Hij zegt: Hebt goeden moed.

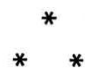

Als de heete strijd eens wijkt,

En men 't hemelsch huis bereikt,

Dan verheft zich 't hart in God verblijd,

Waar het lied van lof en dank,

Wordt gehoord met blij geklank,

En weergalmt door $d^{\prime}$ eeuwigheid.

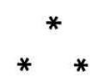

"Strevers Drukkerij" Diyatalawa.

Ceylon.

Offisiere soos Gen P. H. le Roux het ook 'n groot bydrae gelewer tot ' $n$ nasionale gevoel onder die mans. Byvoorbeeld, by die Debatsvereniging op Dingaansdag, was die onderwerp, "Hollands of Afrikaans, die toekomstige taal van Suid-Afrika". Onderwerpe oor die SA geskiedenis is veral aangemoedig "om een karakter bij ons volk te vormen".
Terwyl die meerderheid van die bannelinge aan hierdie kultuur en geestelike bedrywighede deelgeneem het, was daar 'n klein minderheid wat beskryf was as "dobbelaars, sabbatschenders, luiaards en onverschillingen". Daar was ook feesdae in die kamp en geleenthede soos die verjaarsdag van Pres Steijn was met groot geesdrif gevier. Dan kon hulle sing van "het vrije volk" en die optog deur die strate was gekenmerk deur "zingend, juichend en slaande op blikken". Onder normale omstandighede was die Afrikaner baie kalm, maar by hierdie geleenthede kon hy hom tydelik van sy omstandighede onttrek en gelukkig, het die Tommies selde in die Boerefeesvierings ingemeng.

Een van die interessantste ontdekkings ten opsigte van die krygsgevangenes was die stigting van ' $n$ "Boeren-Muziekgeselschap" wat gereeld konserte aangebied het. Opvallend is die keuse van goeie klassieke sowel as ligte musiek. By 'n spesiale Kersfeeskonsert op 24 Desember 1901, het die kamporkes opgetree en onder andere, ' $n$ uitvoering van die Heer B.Alt se oorspronklike komposisie "Die Ragama-Promenadenmarsch" gelewer. Hoeveel nuwe komposisies die lig gesien het gedurende die oorlogsjare, is onbekend, maar dwarsdeur die wêreld het die heldhaftige dade van die Boere komponiste en digters gestimuleer.

Kerkmusiek was met groot geesdrif beoefen en bevorder. In eenvoudige oefeningboeke, soos dié wat op skool as skryfboeke gebruik word, het kamplede sorgvuldig die woorde asook die musiek van die Psalms en Gesange in 4-stemmige Tonic-Solfa notasie uitgeskryf. Hoeveel van hierdie "kamp-boeke" voltooi is, bly onbekend, maar koorsang was een aktiwiteit waaraan almal kon deelneem. Uit ' $n$ kulturele standpunt is hierdie musiekaktiwiteit van merkwaardige betekenis, veral as ons in aanmerking neem dat die TonicSolfa metode eers amptelik in 1894 in Kaapstadse skole gebruik is. Met besondere geduld en liefde, het die kamp-onderwysers hierdie nuwe onderwys-metode aan die eenvoudige plaasboere bekend gemaak. Alhoewel die sing van Psalms nie as die hoogtepunt in musiek kan beskou word nie, lê hierdie prestasie in die feit dat hulle met geesdrif deelgeneem het om hulle lofliedere in 4 stemme te leer sing tot vandag toe nog 'n merkwaardige prestasie vir enige klein plattelandse gemeente. 


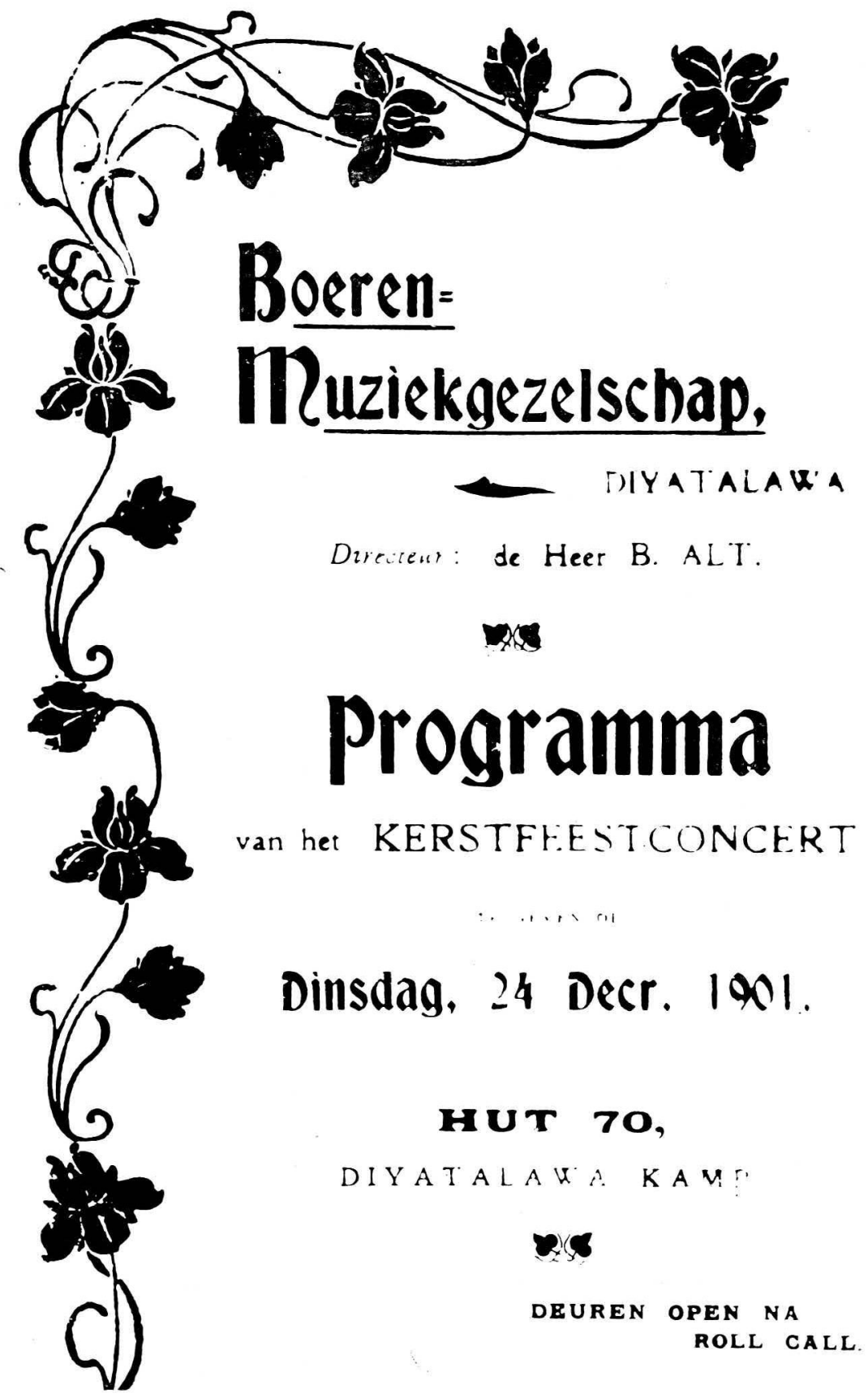




\section{Drei Schiisse}

Burenballade

i) Rudulph Presber

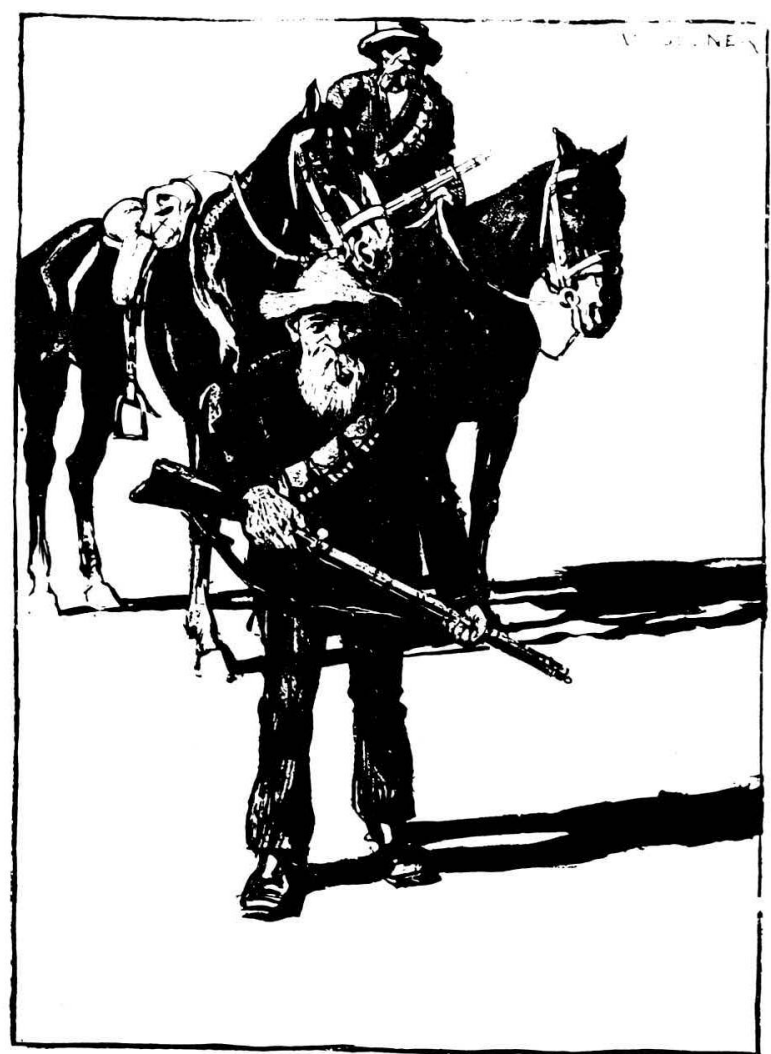

\section{Componrt yon Bernard $Z_{\text {weers }}$}

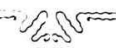

Amsterdam * Van Holkema \& Warendorf 


\section{Drei Schüsse.}

Bernard Zweers.
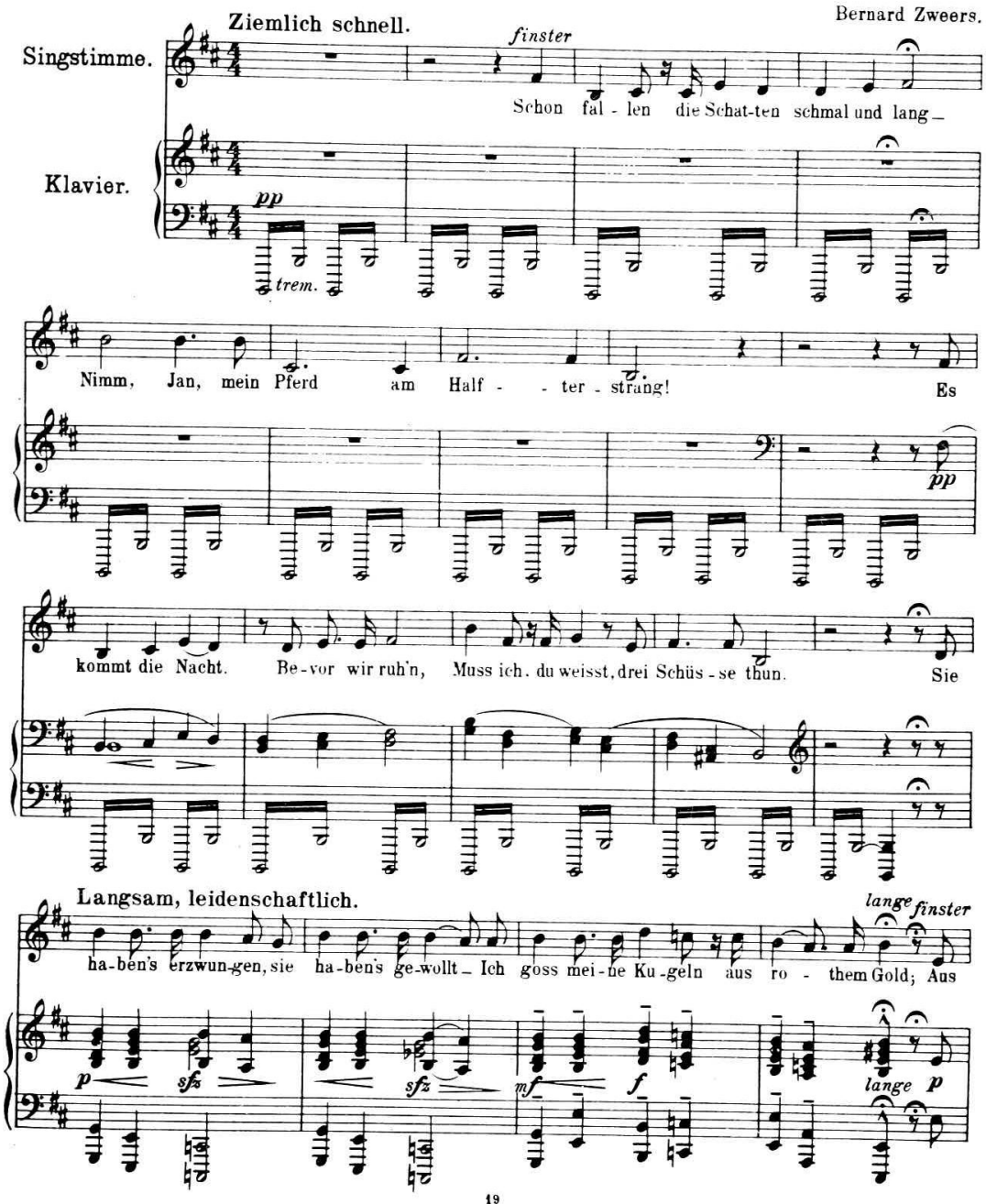


\section{Een Boeren-ballade.}

\section{Drie Schoten.}

De schaduwen groeien;'t licht wordt loom -

Houd, Jan, mijn paard hier aan den toom.

Nacht komt. Ge weet voor't slapen-gaan

Drie schoten moetener zijn gedaan.

Ze hebben grewild het, het heeft ze berouwd-

Ik goot mijn kogels, uit goud, uit goud;

Vit rood, gloeiend goud, dat in bergen lagDrie schoten verschiet ik iedren dag.

En als de eerste kogel raakt,

Een schreiende bruid, 's nachts op't Eiland ontwaakt.

En als er de tweede zijn doel-wit vindt, Dan jammert in Londen een Graven-kind.

En is mijn laatste de loop ontvloôn, Verliest daarginder een Croesus zijn zoon-

Drie kuilen graven ze morgen, stom,

Drie krijschende gieren kring'len er om.

Daarin gaan drie kuapen, van glorie zot,

Geschoten in 't hart door mijn gouden schot.

Daar liggen ze stil en daar liggen ze warm, Als die drie van mij onder't puin van de farm.

Drie moeders echter zijn zekerlik,

In 't rijke Lunden zoo arm, als ik.

'k Heb geen vrouw en geen kind meer, geen dak en geen hujs, Wel goud_en dat is er mijn kogel-spijs.

(Wèl goud, dat diep in mijn bergen lag -

Drie schoten schiet ik iederen dag.

Jac. van Looij. 
Konserte is gereeld ingelei en gesluit deur ' $n$ predikant (of sendeling of ouderling) met skriflesing en gebed. Voordrag en resitasie (soms oorspronklike stukke) is deur aandagtige gehore geniet, en die intellek is soms ook gestimuleer deur kort praatjies soos, "Het leven van Maarten Luther".

Die bydrae tot die lettere is menigvuldig en honderde onbekende (en nou verlore) gedigte het gedurende hierdie tydperk die lig gesien. Ballingskap het ongetwyfeld die talente van sommige burgers gestimuleer, en dit sal byvoorbeeld interessant wees om te bepaal hoeveel gedigte geinspireer is deur die groot Boereheld, Generaal C. R .de Wet. 'n Aantal van hierdie gedigte is op die wysies van bekende sekulêre en geestelike liedere gesing, soos die volgende waarvan net die eerste twee verse aangehaal word:

Wie noemt gij wel een flinke vent? De Wet.

Bij Boer en Engelschman bekend? De Wet.

Wie heeft John Bull zoo vaak verrast?

Zijn trein en mannen aangetast?

't Is Christiaan de Wet! 't Is Christiaan de Wet!

Wie is de held van Koornspruit? De Wet.

Wie won daarbij een groote buit? De Wet.

Wie is nu daar en dan weer hier? Wie vliegt van Vaal naar Grootrivier?

't Is Christiaan de Wet! 't Is Christiaan de Wet!

Plaaslike musici, veral sangers, het altyd vrywillig hulle dienste by konserte aangebied, soos byvoorbeeld: mev. Cumberland, die eggenote van die magistraat; dr Garvin, die hoofdokter, sy eggenote en dogter; mnr Messiner, wat by een konsert die Krygslied uit Tannhäuser, met orkesbegeleiding gesing het; en mej. Vondadelszen, ' $n$ verpleegster in die hospitaal wat by verskillende geleenthede gesing en selfs die gebruik van haar klavier toegestaan het. Na die oorlog is sy met ' $n$ mnr. Diemont, 'n Boere-oppasser in die hospitaal, getroud.

Gedurende oorlogtyd is die insameling van fondse ' $n$ normale aktiwiteit. Baie van die ouer geslag kan nog onthou hoe Ouma Smuts gedurende die Tweede Wêreldoorlog fondse ingesamel het vir die "boys up north". Maar, gedurende die Tweede Vryheidsoorlog het soortgelyke organisasies nie op 'n groot skaal in Suid-Afrika bestaan nie. Eienaardig, maar in hierdie oorlog vind die omgekeerde van hierdie proses plaas - dit is die arm krygsgevangenes wat al hulle "spaargeldjies" insamel en bydra tot ' $n$ "Weduwen en Weezen Fonds". Oorspronklik was dit miskien bedoel vir die families van mede-krygsgevangenes wat oorlede is. Later, toe die treurige berigte uit Suid-Afrika ontvang is oor die toestand van vroue en kinders in die konsentrasiekampe, is die insameling van fondse ywerig voortgesit. Oor hierdie episode, skryf Brink,

“Hun verlies is hartverscheurend en tog wanhopen zij niet, want de liefde tot hun land en nationale onafanklikheid is verreweg te sterk." (bl. 107).

Op 25 Julie 1901, toe die nuus ontvang is van die 1000 ste sterfgeval in die Afrikaanse konsentrasiekampe, het die Boereoffisiere 'n protes, namens die krygsgevangenes van Ceylon, aan die Engelse regering gerig. Die aanbieding van konserte het hierdie fonds aansienlik verhoog.

In teenstelling met St Helena, was die teater die enigste kultuuraktiwiteit wat nie op Ceylon bevorder was nie, maar daar is egter bewys van besoekende geselskappe.

Ons lees gedurig uit algemene bronne van die "uneducated Boors", maar as 'n mens al die kultuuraktiwiteite in die Ceylonkampe objektief beskou, (d w s geloof, opvoedkunde, digkuns, musiek, sport, stokperdjies ens), dan is ons aangenaam verras. Onder hierdie hoofsaaklike plattelandse bevolking was daar ongetwyfeld ' $n$ hoë persentasie met ' $n$ mindere opvoedkundige agtergrond, maar die feit bly staan, dat daar geen gebrek aan geestelike en kulturele leiding bestaan het nie. Hier vind ons miskien 'n uitstekende voorbeeld van die Afrikaanse kultuurlewe op sy allerbeste, en eienaardig genoeg, van ' $n$ hoër gehalte as wat normaalweg in klein plattelandse dorpies te vind is.

\section{Die Ragamakamp:}

Die atmosfeer by die Ragamakamp, wat 9 myl van Colombo was, was heeltemal ongunstig en ongesond. Aangesien dit 40 voet bo seespieël was, was die klimaat drukkend warm (ongeveer 104 grade $F$ in die skadu). Gevolglik het almal tussen 12 middag en $5 \mathrm{~nm}$ 


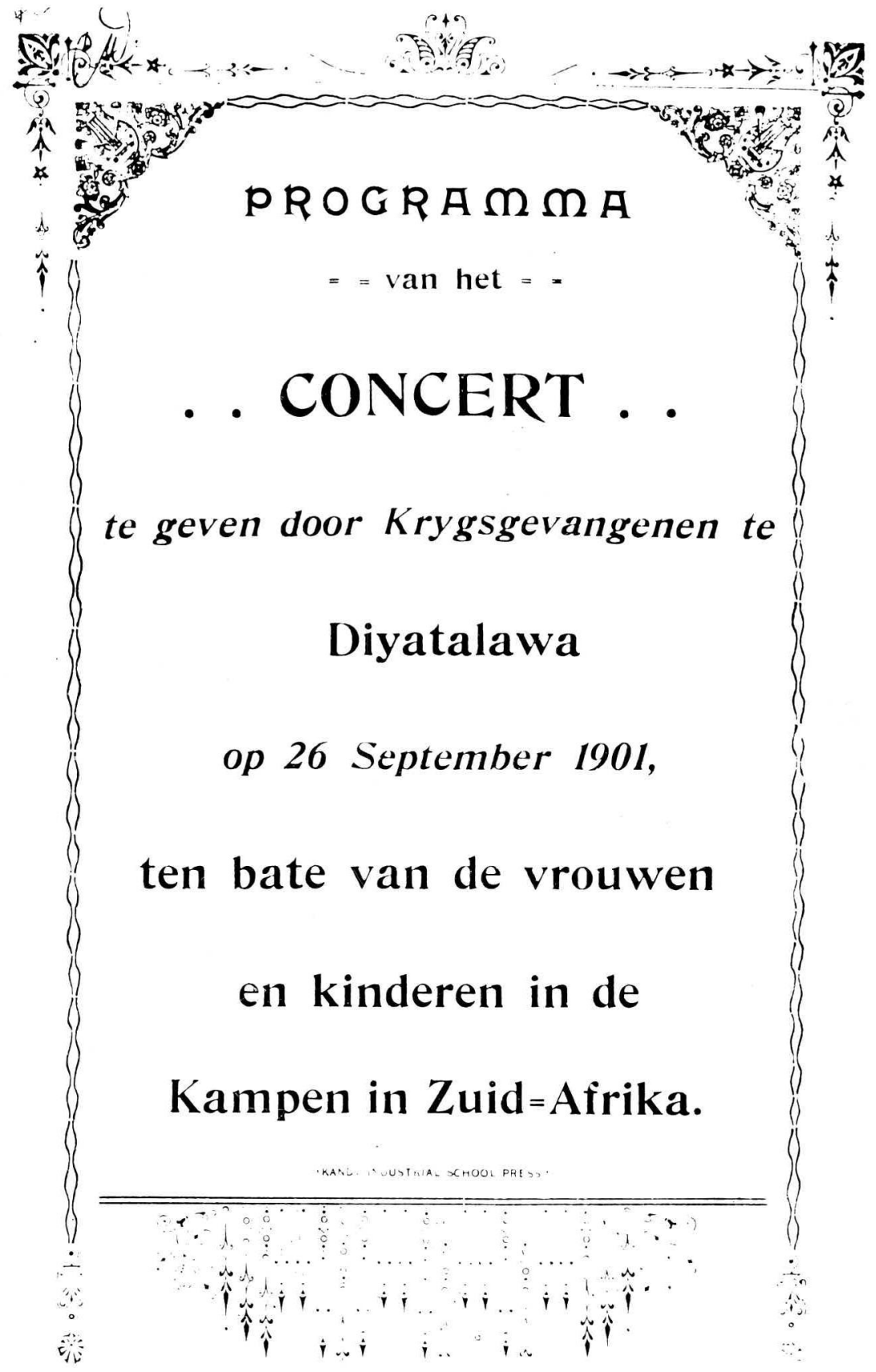

in hulle hutte gebly, en "lights-out" was om $9.45 \mathrm{~nm}$. Ragama was 'n kleiner kamp met ongeveer 300 inwoners, wat in twee kampe verdeel was, met 'n terrein van $250 \times 80$ en $110 \times 110$ jaarts onderskeidelik. Ten spyte van die feit dat Ragama in die skilderagtigste gedeelte van die eiland geleë was, was dit onmoontlik om die omgewing te geniet. Brink skilder 'n sombere prent deur die manne se posisie met "'n onbekende dier in 'n stikdonkere put" te vergelyk.
Veertien verskillende nasionaliteite was hier verteenwoordig. Die meerderheid was egter Hollandse burgers. Volgens 'n brief van Jan $\mathrm{N}$. Brink uit die Kerkbode, is dit opvallend dat onder hierdie nie-Afrikaner krygsgevangenes, "op gebied van godsdienst het leven koud en dood" was. Alle Hollandse volksfeeste, soos die Koningin se verjaarsdag, is met geesdrif gevier. Laasgenoemde altyd vanweë die organisasievermoë van die plaaslike Nederlandse Konsul, de Heer A. Wennink. 
Wennink speel 'n belangrike rol in die maatskaplike lewe van die kamp. Hy verskyn as amptelike skakel tussen die buitewêreld en die krygsgevangenes. Van heinde en ver, hoofsaaklik uit Europa, ontvang hy geldelike bydraes vir die krygsgevangenes van familielede en algemene weldoeners. Dit was sy taak om die inwoners op te spoor, en vir hulle algemene welsyn te sorg. Aangesien sy kantoor op Colombo was, was dit onmoontlik om gereeld die kamp te besoek. Om sy werk te vergemaklik, het hy die kampbevolking so ingedeel, dat alle korrespondensie na en vanaf krygsgevangenes alleenlik deur 'n paar "liaison" offisiere ( $d$ w s mede-krygsgevangenes) behandel moes word. Op die wyse, vind ons ' $n$ interessante briewewisseling tussen Wennink en Krygsgevangene No. 3192, wat nou aan die lig gekom het. Laasgenoemde was Maarten Spies, 'n Nederlandse onderwyser en musikus wat vir ongeveer 10 jaar in die ZAR woonagtig was. Wennink skryf soms in Hollands of in Engels, en altyd in sy eie handskrif. Hier volg nou 'n tipiese brief vanaf Wennink aan Spies:

Colombo.

1st March 1901.

M. Spies, Esq.

Ragama.

Burma cigars and pipes. I have to-day forwarded to you one box containing 1800 cigars and another one containing 30 wooden pipes. H. Sell. I have received his letter and have forwarded his petition as requested.

E. Haverkamp. Will please give me his instructions about Rs.148.50 which I have received for him in a $\mathrm{f10/-note} \mathrm{from} \mathrm{Mr.} \mathrm{Louis} \mathrm{de}$ Veer, Amsterdam. I shall not write to Mr. De Veer, but shall leave this to Mr. Haverkamp. D. D. Thle. Please hand this gentleman enclosed letter from Cargills Linniter.

\section{Yours faithfully,}

A. WENNINK,

Consul for the Netherlands. ${ }^{1}$

'n Groot aantrekkingskrag by Ragama was die "Camp Stores" en om die aankoop van inkupies te vergemaklik, is spesiale kredietnote gedruk. Wanneer die "Camp Stores" nie alles kon voorsien nie, het die manne die Konsul versoek om benodigdhede soos kos,

\footnotetext{
1 Staatsargief, Pretoria. A.560 B.1,640.
}

klere en tabak te bestel. Sommige van die versoeke is nogal interessant. Byvoorbeeld, een krygsgevangene wou baie graag ' $n$ Duitse grammatika bestel, terwyl 'n ander "dumbells" wou hê, en uit een brief aan Spies, skryf Wennink, "Pyjamas en pantoffels kan ik niet geven. Ceylon is het land om blootsvoet te loopen". Wanneer hy nie plaaslik voorrade kon koop nie, het hy vanaf Europa bestel. Benewens sy pligte as "algemenewinkelier", moes hy ook as maatskaplikebeampte optree, want daar is talle verwysings omtrent verlore Hollandse burgers wat nie briewe uit Nederland beantwoord het nie. Die enigste versoek wat Wennink geweier het, was 'n kaart van Ceylon! Plaaslike geskenke, soos botter en konfyt vanaf Rangoon, asook die aflewering van (beskikbare) weeklikse vars groente, is ook persoonlik deur hom gereël, en hy het altyd versoek dat hierdie geskenke onder die "armste" krygsgevangenes verdeel moes word.

Van belang was die bestaan van 'n spesiale tak op Ragama van die "Ceylon Ice and Cold Storage Company, Colombo". Die "Camp Stores" was ongetwyfeld 'n florerende sakeonderneming, en in Junie 1901, het hulle 'n spesiale goederelys laat druk. Hier volg nou 'n alfabetiese opsomming van hierdie lys:

Biscuits (Verskillende soorte), blanco, brawn, butter, cakes, cheese, cigars, cocoa, coffee, corned beef, curry powder, enos, fish (tinned), golden syrup, ice, ink, jams (Australian), jellies, marmalade, matches, milk (condensed), mushrooms, oatmeal, pepper, playing cards, sauces, sausages (tinned), soap (per cake 15c), sugar, tobacco, vegetables (tinned), vinegar, waters aerated ( $d$ w s koeldranke), en verder, "English fish and Australian beef, mutton and lamb, when in stock".

Die Tweede-Vryheidsoorlog het op hierdie wyse die handelsbedryf gestimuleer, veral die vervaardiging van "blikkieskos", soos konfyt. Dit is eienaardig, maar dit was gedurende hierdie oorlog dat die ingelegde-vrugtenywerheid in die Westelike Provinsie tot stand gekom het - hoofsaaklik om die Britse troepe in Suid-Afrika met kos te voorsien.

Volgens Brink, was die daaglikse rantsoen soos volg:

$\frac{3}{4} \mathrm{lb}$. brood : $\frac{3}{4} \mathrm{lb}$. vleis : $\frac{1}{4} \mathrm{lb}$. bone : 10 onze aardappels : 2 onze rys : $1 / 5$ on. 
sout : $1 / 5$ on. limejuice : $\frac{1}{4} \mathrm{lb}$. jam per week : $1 / 12 \mathrm{lb}$. melk : $1 / 5 \mathrm{lb}$. seep per week : $5 / 7$ on. tee of $1 \frac{3}{4}$ on. koffie : 2 on. suiker.

Beskrywings van die vleis ("blou", "taai", "stink"), dui aan dat die Afrikaner in dié opsig, hom nooit by sy veranderde omstandighede aangepas het nie.

Weens die ongunstige, warm klimaat van Ceylon, is dit vanselfsprekend dat siektes onder die krygsgevangenes uitgebreek het. So is byvoorbeeld, 80 Boere tussen Oktober en Desember 1900 oorlede aan maagkoors, terwyl honderde ligte aanvalle daarvan gehad het. Verwysings na gesondheid en die geestelike toestand van die krygsgevangenes is algemeen in hulle briewe, maar die tekorte aan geld het sommige hard getref, soos byvoorbeeld uit hierdie brief:

Liefste Vader en Moeder, - Wij zijn hier veilig aangekomen. Het is een heerlijke plaats. Ik heb al mooi plekken gezien maar niet een wat zoo lijkt.

Door de genade Gods gaat het met mij nog goed en ik wensch u hetzelfde.

Ik wensch dat ik vrij was, zoodat ik die plek van end tot end kon onderzoeken.

Toen wij het schip verlieten klommen wij op den train en wij gingen door 36 tunnels onder de bergen, dus kan u zelf beoordelen welk soort van een land het is. Onze reis per train nam minder dan een dag.

Moet niet praten van plantagies, Bananas, Klappers, Dadels, Koffie, Zuiker en alles wat de aarde opbrengt - het is onmogelijk om een beschrijving van de plek te geven.

Wij worden goed behandeld. Al wat ik noodig heb is geld. Stuur mij als $u$ blief een weinig geld. Het gaat zwaar om zonder het klaar te komen. Ik kon niet eerder schrijven door gebrek van inkt en papier. Stuur het geld zoodra als $u$ deze brief ontvangt.

\section{MARTHINUS PELSER,}

Boer gevangenen Kamp,

Ceylon

Uit 'n militêre standpunt is die Tweede-Vryheidsoorlog 'n ongelukkige bladsy uit ons volksgeskiedenis, maar, soos skrywer hier probeer aandui het in hierdie kort skets, weerspieël dit 'n belangrike mylpaal in ons kultuurgeskiedenis. Hier vind ons 'n ideale weerspieëling van die karakter van die algemene Afrikaanse burger in die tydperk teen die einde van die 19e eeu. Die Boer het wêreldberoemdheid vir sy dapperheid in die veld verwerf, tog was hy nie 'n opgeleide, gedissiplineerde soldaat nie. Sy sterk innerlike krag, sy geduld, gehoorsaamheid, patriotisme, ondernemingsgees, optimisme en die krag van sy geloof gedurende sy ballingskap bly 'n lewendige monument vir ons onbekende en vergete helde van die verlede tot inspirasie vir die nageslag. Ten slotte, skryf krygsgevangene $H$. S. Kok soos volg:

"Wij kunnen getuigen van veel zegen, dien wij met Kersfees en Nieuwejaar ontvangen hebben. Het is inderdaad de heerlijkste dagen die ik doorgebracht heb.

De ballingskap van Ceylon was mij waarlijk een goede leerschool."

\section{BIBLIOGRAFIE:}

Brink, J. N.: Ceylon en de Bannelingen (Amsterdam-Kaapstad, Hollandsch-Afrikaansch Uitgevers Maatschappij, v/h Jac. Dusseau \& Co, 1904).

\section{BRONNE:}

1. Argief, Nasionale Oorlogsmuseum, Bloemfontein; verskillende dokumente, ens.

2. Staatsargief, Pretoria. Versameling van Maarten Spies, A.560.

3. Die Kerkbode, Deel XIX, Nr 19, 15 Mei 1902, bl 363; briewe deur: H. S. Kok (J.zoon) en Jan N. Brink.

4. Ons Klyntji, Jaargang $5, \mathrm{Nr} 9$, September 1900, bl 182; brief Marthinus Pelser.

5. De Strever (Orgaan der CSV onder de Krygsgevangenen), 19 Desember 1901-9 Augustus 1902, Ceylon.

6. Nasionale Dokumentasiesentrum vir Taal en Lettere, Raad vir Geesteswetenskaplike Navorsing, Pretoria.

7. Nasionale Musiek-dokumentasiesentrum, Raad vir Geesteswetenskaplike Navorsing, Pretoria.

8. Africana Museum, Johannesburg.

\section{Dankbetuiging:}

Dr. A. C. Symington, Hoofdokumentrise, Nasionale Dokumentasiesentrum, Pretoria. 